\title{
51 \\ Dreaming of Diversity in Legal Education
}

\author{
Margaret Thornton ${ }^{1}$
}

\section{Introduction}

The compulsory core of legal education has not changed markedly since law was first taught in the university in the $19^{\text {th }}$ century, despite extensive social change. Most recently, we have witnessed the transformation of the legal profession, state disinvestment in public universities, a proliferation of law students and a raft of new law schools. Against this backdrop, I question the wisdom of continuing to adhere to a standardised 'core' curriculum and uniform admission rules when less than 50 per cent of law graduates go into private practice and remain there.

I outline the trajectory of change and make some suggestions as to the way forward. I argue that the case for diversity of the law curriculum should be placed squarely on the legal education agenda. I recommend that the Priestley 11 be abandoned, allowing law schools to focus on their individual strengths. Specialisation in the context of a broad liberal education would not only be academically desirable, it would also better equip graduates for a diverse range of destinations.

1 Professor of Law, The Australian National University. 


\section{The Production of Law Graduates}

Australian higher education was radically transformed when all colleges of advanced education (CAEs) were incorporated into a unified higher education system in 1989, which led to the creation of 16 new universities in four years. ${ }^{2}$ Despite the orchestrated transition from an elite to a mass system, there was not a commensurate increase in public funding, which led to a shift from free higher education to a user-pays regime. The number of Australian law schools then rapidly increased as the new vice-chancellors believed that law could be taught cheaply and the income would help to subsidise the more resource-intensive parts of the university. Differential rates for HECS were introduced in 1997, with law at the top rate, ${ }^{3}$ but this had no discernible effect on the demand for law places.

In 25 years, the number of law schools has more than tripled - from 12 to 40 across 47 campuses, including Australia's first for-profit law school. ${ }^{4}$ Government disinvestment in higher education also encouraged established law schools to increase their intakes, which were boosted by the lifting of the cap on Commonwealth-funded places and the introduction of the Juris Doctor (JD). The increase in law graduation rates has been phenomenal:

\begin{tabular}{|l|l|}
\hline Year & No of Graduates \\
\hline 1984 & 1,932 \\
\hline 2001 & 6,149 \\
\hline 2014 & 14,600 (all u/grad \& p/grad law programs) \\
\hline
\end{tabular}

Source: Edmund Tadros and Katie Walsh, 'Too Many Law Graduates and Not Enough Jobs', Financial Review, 22 October 2015, www.afr.com/business/legal/too-many-law-graduatesand-not-enough-jobs-20151020-gkdbyx. The collection of precise disaggregated data is difficult and confusing because of the varied approaches adopted by the federal, state and territory authorities. The Australian Council of Law Deans settled on a total of 7,583 LLB and JD graduates in 2015. See Melissa Coade, 'Counting the So-called 'Glut' of Law Grads', Lawyers Weekly, 25 November 2016, www.lawyersweekly.com.au/news/20080counting-the-so-called-glut-of-law-grads. This figure did not include other sources of graduate lawyers, such the Legal Profession Admission Board of NSW, which produced 166 graduates in 2015-16 (NSW Department of Justice, Annual Report 2015-16, www. Ipab.justice.nsw.gov.au/Documents/Annual\%20Report\%202015-16.pdf).

2 Simon Marginson and Mark Considine, The Enterprise University: Power, Governance and Reinvention in Australia (Cambridge University Press, 2000) 29.

3 Along with medicine, dentistry and veterinary science, www.aph.gov.au/About_Parliament/ Parliamentary_Departments/Parliamentary_Library/Publications_Archive/archive/hecs.

4 TOP Education Institute, Sydney City School of Law: Australia's Newest Law School (2016), www.top.edu.au/home/school-of-law. 


\section{Sameness or Difference?}

One would have thought that the proliferation of so many new law schools presented an ideal opportunity for diversifying the law curriculum. However, it had the opposite effect. Because the admitting authorities were suspicious of the new schools, they favoured uniformity. Indeed, the adoption of uniform admission rules (the 'Priestley 11'5) coincided with the establishment of the first wave of new schools in the early 1990s.

Theoretically, completion of the Priestley 11 was not necessary for a student to graduate with an LLB but, out of deference to the profession, the 11 prescribed areas of knowledge were incorporated into each university's compulsory curriculum. Indeed, no Australian law school was brave enough to bypass Priestley and specify an alternate set of requirements, except one, although the attempt was short-lived. When La Trobe began its LLB program in 1992, only two subjects were specified as compulsory: Legal Reasoning and Socio-legal Research Methods. However, within two years and before the first cohort had even graduated, the newly-ratified Priestley 11 was made compulsory for the award of the LLB, although most students had chosen to include the specified areas of knowledge in their course of study anyway - 'just in case' they decided to take out a practising certificate. ${ }^{6}$

It is notable that the Priestley Committee ignored the broadening of the curriculum that had been occurring in law schools since the 1970s, choosing to prioritise doctrinal and technical competence over context and critique. The Victorian Council of Legal Education (the rules for which became the model for the Australian Uniform Admission Rules) rejected family law in favour of company law in 1990 on the basis that 'the building block components of family law were covered by "contract, property and trusts"'; 7 gender, affectivity and family relations were deemed dispensable.

5 After Justice Priestley who chaired the Law Admissions Consultative Committee of State and Territory Law Admitting Authorities in 1992. The specified areas of knowledge are Criminal Law and Procedure, Torts, Contracts, Property, Equity (including Trusts), Company Law, Administrative Law, Federal and State Constitutional Law, Civil Procedure, Evidence, Ethics and Professional Responsibility.

6 Margaret Thornton, Quinquennial Professorial Report to University Council (La Trobe University, Melbourne, 1995), on file with the author.

7 Council of Legal Education Victoria, Report of Academic Course Appraisal Committee on Legal Knowledge Required for Admission to Practise (Council of Legal Education Victoria, 1990). 
As in Canada, Priestley accorded short shrift to non-doctrinal subjects with a long academic tradition, such as legal theory and legal history. ${ }^{8}$ The centripetal pull of technocratic business-oriented law and the imprimatur of the admitting authorities determined what was important, underscored by the credentialism and vocationalism that accompanied the user-pays mentality. ${ }^{9}$ Even the fact that the Pearce Report had recognised the generalist nature of the law degree only a few years earlier was accorded short shrift.

The deference towards the admitting authorities underscores not only the subordination of law schools to the legal profession but also the failure of law to develop as an independent discipline within the academy. ${ }^{10}$ The expansion of law schools would have been an ideal time to argue for diversity but there is an absence of unanimity among academics as to just what the primary role of a law school should be - a site for the training of practitioners or an independent academic discipline. In recent years, the scales have tipped away from a liberal legal education in favour of vocationalism, entailing deference to known knowledge. Even from a functional perspective, however, one would have to query whether having 40 virtually identical programs is economically rational. The uniformity of the curriculum arises from what Thomasset and Leperrièrre refer to as the infeudation of law schools to the profession. ${ }^{11}$ They suggest that the domination of the profession is such that there would need to be a revolution to slough it off.

\section{Challenging Priestley}

The Priestley 11 has been subject to criticism over the years, not only from those seeking a more liberal orientation to legal education, but also from legal practitioners themselves who have felt that inadequate attention was being paid to what lawyers actually do. ${ }^{12}$ The response led to the

8 Cf Harry Arthurs, "Valour Rather than Prudence”: Hard Times and Hard Choices for Canada's Legal Academy” (2013) 76 Saskatchewan Law Review 73, 86.

9 Margaret Thornton, Privatising the Public University: The Case of Law (Routledge, 2012) 59-109.

10 Cf Mary Keyes and Richard Johnstone, 'Changing Legal Education: Rhetoric, Reality, and Prospects for the Future' (2004) 26 Sydney Law Review 537, 542.

11 Claude Thomasett and René Leperrièrre, 'Faculties under Influence: The Infeudation of Law Schools to the Legal Professions' in Fiona Cownie (ed), The Law School: Global Issues, Local Questions (Ashgate, 1999).

12 Australian Law Reform Commission, Managing Justice: A Review of the Federal Civil Justice System (Report No 89) (2000), 123-27. 
incorporation of more practice-related skills into the curriculum, ${ }^{13}$ but the effect was to induce not only a less liberal orientation to the law degree but also an instantiation of the idea that traditional legal practice is the logical destination for all law graduates.

In 2015, the Law Admissions Consultative Committee (LACC) proposed a limited review of the academic requirements for admission, influenced by the Legal Education and Training Review conducted in England and Wales in 2013. ${ }^{14}$ LACC wanted to know whether civil procedure, company law and evidence, together with ethics and professional responsibility, should continue to be prescribed areas of knowledge and whether statutory interpretation should be included as a new academic requirement. ${ }^{15}$

The key question is whether a designated area of knowledge is foundational to a law degree, not whether it is a useful addition. It is suggested that civil procedure, company law and evidence could all be omitted as they are included in the PLT Competency Standards, but ethics and professional responsibility should be retained. To focus on legal doctrine, or law as it is, is to teach frozen knowledge that is likely to be out of date by the time the student graduates. The focus should be on principles and transferable knowledge. Ethics and professional responsibility are foundational, not only to legal practice, but to most areas of employment. The inclusion of statutory interpretation is also supported. Not only do we live in an age of statutes, but the principles and techniques of interpretation are poorly understood. As with ethics, interpretative skills possess a high degree of transferability, for they are central to all linguistic and text-based disciplines, including law and public policy.

I also note that the Priestley 11 remains resolutely domestic in its orientation, despite the reality of globalisation, although a report commissioned by the Australian Government Office for Learning and Teaching in 2012 recommended that the law degree be internationalised,

13 Thornton, above n 9, 81-84.

14 Legal Education and Training Review (LETR) of England and Wales (viewed 21 March 2016), letr.org.uk/wp-content/uploads/LETR-Report.pdf.

15 LACC had not reported at the time of writing. 
favouring a 'light-handed' approach by the admitting authorities. ${ }^{16}$ Some stakeholders nevertheless expressed strong support for making private international law compulsory within the Priestley $11,{ }^{17}$ which reflects law firms' emphasis on profit maximisation.

\section{Towards Diversity in Legal Education}

Less than 50 per cent of law graduates embark on a career in private law firms ${ }^{18}$ while the remainder pursue a diverse range of careers in the public service and the non-profit sector, business and finance, international institutions such as the United Nations, as well as journalism, research and teaching positions. Why, then, should they be compelled to undertake an expensive legal education predicated on the assumption that they will embark on private practice and earn substantial salaries on the corporate track? ${ }^{19}$ In any case, as the total number of solicitors in Australian law firms is just over $66,000,{ }^{20}$ it would be impossible to place the majority of graduates in law firms. Of course, law schools are not responsible for ensuring that their graduates find employment and they are unlikely to be sued if graduates are unsuccessful, as has occurred in the US. ${ }^{21}$ However, vocationalism is a dimension of government policy that law schools cannot afford to ignore.

16 Office for Learning and Teaching, Department of Industry, Innovation, Science, Research and Tertiary Education (Australian Government), Internationalising the Australian Law Curriculum for Enhanced Global Legal Practice (Australian Government Office for Learning and Teaching, 2012) 86, www.olt.gov.au/resource-internationalising-australian-law-curriculum-enhanced-globallegal-practice-2012.

17 Ibid. 69.

18 A 2010 survey by Graduate Careers Australia revealed that only 43.7 per cent of graduates started work in law firms (a drop from 49.1 per cent five years earlier). See Nicola Berkovic, 'Fewer Law Graduates are Choosing Practice as a Career', The Australian (online), 1 July 2011, www. theaustralian.com.au/business/legal-affairs/fewer-law-graduates-are-choosing-practice-as-a-career/ story-e6frg $97 \mathrm{x}$-1226085138499. In the US, 55 per cent of law graduates were employed in full-time, bar passage-required employment nine months after graduation in 2011. See William Henderson, 'A Blueprint for Change' (2013) 40 Pepperdine Law Review 461, 475.

19 In 2016, the cost of a Commonwealth-supported place for Law was $\$ 44,000$ and set to rise to $\$ 58,000$ according to predictions of the Australian Scholarships Group. See Australian HES online, 1 March 2016, www.theaustralian.com.au/higher-education.

20 Law Council of Australia, www.lawcouncil.asn.au/lawcouncil/index.php/12-resources/231how-many-lawyers-are-there-in-australia.

21 Elizabeth Olson, 'Law Graduate Gets Her Day in Court, Suing Law School', New York Times, 7 March 2016, www.cnbc.com/2016/03/07/law-graduate-gets-her-day-in-court-suing-law-school.html. 
In 2011-12, most of the top-tier Australian corporate law firms became globalised as a result of amalgamation with London-based 'Magic Circle' firms. ${ }^{22}$ The aim was to maximise profits. Efficiencies were also introduced, such as resorting to companies specialising in document review, discovery and predictive coding in order to undertake more cheaply work traditionally performed by associates. The emphasis on profit maximisation has meant that law firms may no longer be prepared to assume responsibility for training substantial numbers of new graduates, who could find themselves vying with cheaper paralegals for entry-level positions.

Contrary to the uniformity of destination anticipated by the admitting authorities, there is increasing pressure on law firms to diversify ${ }^{23}$ and there is criticism from within the profession that students have not had sufficient exposure to alternative forms of employment, such as corporate in-house roles. ${ }^{24}$ Social justice advocates are also critical of the notable shortages of lawyers in regional, rural and remote areas and the fact that ordinary citizens cannot afford access to legal services. ${ }^{25}$ Despite such needs, traditional legal practice, particularly corporate practice, continues to be regarded as the raison d'être of legal education.

Even if graduates enter traditional legal practice initially, they are unlikely to remain on a single career trajectory. A recent study of Millennials (those born after 1982) found that 46 per cent expect to leave their current employer within the next two years. ${ }^{26}$ The Pearce Report noted 30 years ago that more than 50 per cent of law graduates were entering diverse destinations, but the curriculum has failed to take adequate cognisance of this reality, despite the explosion in numbers. It is therefore time that we thought more creatively about the inclusion of transferable skills in the law curriculum with an eye not only to actual student destinations but also to

22 Margaret Thornton, 'Hypercompetitiveness or a Balanced Life? Gendered Discourses in the Globalisation of Australian Law Firms' (2014) 17(2) Legal Ethics 153.

23 Stefanie Garber, 'Firms Urged to Push into Non-legal Sectors', Lawyers Weekly, 17 February 2016, www.lawyersweekly.com.au/news/17993-firms-urged-to-push-into-non-legal-sectors.

24 Stefanie Garber, 'Students Underexposed to In-house Roles', Lawyers Weekly, 17 February 2016, www.lawyersweekly.com.au/news/17998-students-underexposed-to-in-house-roles.

25 Productivity Commission (Australian Government), Access to Justice Arrangements: Productivity Commission Inquiry Report (Productivity Commission, 2014).

26 Felicity Nelson, 'Young Lawyers View Staying Put as "Career Suicide", Lawyers Weekly, 10 February 2016, www.lawyersweekly.com.au/careers/17953-young-lawyers-view-staying-put-as-career-suicide. 
their educational benefits. Attention should be paid to problem solving, leadership, ethics, values, project management and creative thinking, as well as sociolegal research methods and interdisciplinary perspectives. ${ }^{27}$

The issue of diversity in destination begs the question of whether difference rather than sameness should be addressed by the admitting authorities, although the signs are not propitious. When Alfred Reed suggested in 1921 that different 'bars' be created in the US, this was regarded as heretical. ${ }^{28}$ Would it be possible to develop varying gradations of admission in Australia today? Should we effect a divorce from Priestley in the interests of a more diverse and dynamic curriculum?

The divorce could entail separating the admission and the academic requirements, with a national exam to follow practical legal training for those who wished to be admitted. Although the administration of such an exam would be cumbersome, it could be managed by state and territory admitting authorities or the Law Council. However, as Thomasett and Leperrière make clear, a separate exam would not necessarily overcome the problem of infeudation, as whatever subjects are specified by the admitting authorities tend to influence the content of the law curriculum, even if no longer compulsory. ${ }^{29}$

I believe that it should be made clear to students at the outset that legal practice is only one of many possible destinations for them. Accordingly, law schools should be free to design their own curricula. Each school could designate as compulsory certain basic areas of knowledge, such as contract and constitutional law, followed by specialisation in a cluster of cognate subjects, comparable to a major in the BA. Specialist streams could be devoted to human rights, gender, race, crime, international law, comparative law, environmental law, public law, commercial law, etc., in addition to more general offerings. I particularly want to exhort a shift away from an obsession with doctrine to a focus on transferable skills, as suggested, including negotiation, conflict resolution and an ethical consciousness appropriate for a dynamic global environment. This is where the role of collaboration rather than adversarialism, as advocated

27 Cf Keyes and Johnstone, above n 10, 541.

28 Richard W Bourne, 'The Coming Crash in Legal Education: How We Got Here, and Where We Go Now' (2011/2012) 45 Creighton Law Review 651, 696.

29 Thomasett and Leperrière, above n 11, 198. 
by Pauline Collins, ${ }^{30}$ would come into its own. In reimagining the curriculum, I am not ignoring vocationalism, for a broad liberal education would better prepare students for a wide array of destinations in which a law degree would be advantageous.

\section{Conclusion}

I suggest taking a leaf out of the report of the Ontario Higher Education Quality Council regarding differentiation among universities in Ontario in 2013, ${ }^{31}$ which argued that the funding formula should be amended to ensure that the province's 20 universities have the resources to enable them to pursue a policy of achieving what each one does best. How much more sensible it would be for the Australian Government to do the same in respect of 40-plus law schools rather than accept that they all should be pale copies of one another.

Elements of diversity of a socioeconomic nature can be discerned as new schools struggle to compete with those possessing significant positional goods arising from age, wealth and metropolitan location. However, is entrenching class differences between the 'haves' and the 'have nots' the type of diversity that we wish to promote? A liberal legal education that focuses on critical thinking, values, principles and ethics in the context of diverse curricula offerings undoubtedly provides a superior education for law students, as well as constituting better preparation for a range of positions in a context of dynamic and uncertain social change.

30 Pauline Collins, 'Australian Legal Education at a Cross Roads' (2016) 58(1) Australian Universities' Review 30.

31 Higher Education Quality Council of Ontario, The Diversity of Ontario's Universities: A Data Set to Inform the Differentiation Discussion (Higher Education Quality Council of Ontario, 2013), www. heqco.ca/SiteCollectionDocuments/HEQCO\%20Diversity_ENG.pdf. 
This text is taken from New Directions for Law in Australia: Essays in Contemporary Law Reform, edited by Ron Levy, Molly O’Brien, Simon Rice, Pauline Ridge and Margaret Thornton, published 2017 by ANU Press, The Australian National University, Canberra, Australia. 